\title{
УДК: 35.077
}

Напльоков Юрій Васильович, магістр стратегічних наук, магістр військових наук та військового мистецтвва, старший викладач кафедри підготовки миротворчого персоналу, Національний університет оборони України ім. Івана Черняховського, полковник, аспірант кафедри менеджменту $i$ адміністрування Харківського начіонального університету міського господарства ім. О. М. Бекетова, 03049, м. Київ, Повітрофлотський проспект, 28, тел.: +38 (098) 24213 53, e-mail:designyzn@gmail.com

ORCID: 0000-0002-0343-8337

\section{Наплёков Юрий Васильевич,}

магистр стратегческих наук, магистр военных наук и военного искусства, старший преподаватель кафедры подготовки миротворческого персонала, Национальный университет обороньь


Украины им. Ивана Черняховского, полковник, аспирант кафедры менеджмента и администрирования Харьковского национального университета городского хозяйства им. А. Н. Бекетова, 03049, г. Киев, Воздухофлотский проспект, 28, тел.: +38 (098) 242 1353,e-mail:designyon@gmail.com

ORCID: 0000-0002-0343-8337

Naplyokov Yuriy Vasilievich,

Master of Strategic Sciences, Master of Military Art and Science, senior lecturer of the department of training of peacekeeping personnel, National Defense University of Ukraine named after Ivan Chernyakhovsky, Colonel, postgraduate student of the Department of Management and Administration of Kharkov National University of Municipal Economy named after O. M. Beketov, 03049, Kyiv, Povitroflotsky Prospect, 28, tel.: +38 (098) 24213 53, e-mail: designyvn@gmail.com

\section{МОДЕЛЬ ДЕЛЕГУВАННЯ КЕРІВНИЦТВА МІЖ ДЕРЖАВНОЮ ВЛАДОЮ ТА ГРОМАДЯНСЬКИМ СУСПІЛЬСТВОМ}

Анотація. Представлено модель делегування керівництва між державною владою (ДВ) та громадянським суспільством (ГС), щоб зробити державне управління ефективним в умовах складного та динамічного середовища. Модель сприятиме виявленню ступеня залучення ДВ та ГС до керівництва дер- 
жави відповідно до складності, невизначеності та динаміки змін середовища та держави (системи).

Участь ДВ та ГС у керівництві державою є критичною, щоб зробити систему розумною й ефективною. Це вимагає належного застосування лідерської сили, зміни стилів керівництва та, нарешті, організаційної структури, засновуючись на ситуації. Змінне середовище вимагає адаптації системи та/або формування середовища для встановлення рівноваги між системою та середовищем. Це можливо завдяки належній участі ДВ та ГС у процесі прийняття рішень (ППР). Разом вони мають визначити коріння проблеми, аналізувати їі та виробляти рішення для адаптації системи та/або впливу на середовище різними синхронними й узгодженими діями на основі синергетичного ефекту.

У змінному середовищі рівень участі ДВ та ГС у керівництві державою має бути гнучким. Повна децентралізація або централізація з визначеними правилами та положеннями може не дозволити належно делегувати керівництво між ДВ та ГС, щоб зробити систему ефективною. Навіть правильна комбінація ДВ та ГС не може забезпечити успіх через відсутність готовності до їх співпраці. Це може залежати від національної культури, системи держави, бажання людей брати участь у процесі керівництва та інших особливостей. Часто лише менша частина населення активна і готова до інновацій та змін. Щоб зібрати та навчити цих людей, потрібні зусилля, що базуються на відданості національним цінностям, переконанням та альтруїзмі. Проте в перехідний період ці поняття також є змінними і можуть не представляти реальний “національний фундамент”.

Усі наведені причини зумовлюють пошук практичного підходу, коли, де і як розділяти лідерську владу між ДВ та ГС у змінному середовищі.

Ключові слова: лідерство, державна влада, громадянське суспільство, система, середовище, рівновага, коефіцієнт, мислення, ефективність.

\section{МОДЕЛЬ ДЕЛЕГИРОВАНИЯ РУКОВОДСТВА МЕЖДУ ГОСУДАРСТВЕННОЙ ВЛАСТЬЮ И ГРАЖДАНСКИМ ОБЩЕСТВОМ}

Аннотация. Представлена модель делегирования руководства между государственной властью (ГВ) и гражданским обществом (ГО), чтобы сделать государственное управление эффективным в условиях сложной и динамичной среды. Эта модель должна способствовать выявлению степени привлечения ГВ и ГО к руководству государства в соответствии со сложностью, неопределенностью и динамикой изменения среды и государства (системы).

Участие ГВ и ГО в руководстве государством является критическим, чтобы сделать систему разумной и эффективной. Это требует надлежащего применения лидерской силы, изменения стилей руководства и, наконец, организационной структуры, основываясь на ситуации. Изменяющаяся среда требует адаптации системы и/или формирования среды для установления равновесия между системой и средой. Это возможно благодаря надлежащему 
участию ГВ и ГО в процессе принятия решений (ППР). Вместе они должны определить корни проблемы, анализировать ее и вырабатывать решения, чтобы адаптировать систему и / или повлиять на среду различными синхронизованными и согласованными действиями на основе синергетического эффекта.

В изменяющейся среде уровень участия ГВ и ГО в руководстве государством должно быть гибким. Полная децентрализация или централизация с определенными правилами и положениями может не позволить должным образом делегировать руководство между ГВ и ГО, чтобы сделать систему эффективной. Правильная комбинация ГВ и ГО не может обеспечить успех из-за отсутствия готовности к их сотрудничеству. Это может зависеть от национальной культуры, системы государства, желания людей участвовать в процессе руководства и других особенностей. Часто лишь меньшая часть населения активна и готова к инновациям и изменениям. Чтобы собрать и научить этих людей, нужны усилия, основанные на преданности национальным ценностям, убеждениях и альтруизме. Однако в переходный период эти понятия также являются переменными и могут не представлять реальный “национальный фундамент".

Все перечисленные причины обусловливают поиск практического подхода, когда, где и как разделять лидерскую власть между ГВ и ГО в изменяющейся среде.

Ключевые слова: лидерство, государственная власть, гражданское общество, система, среда, равновесие, коэффициент, мышление, эффективность.

\section{A MODEL OF DELEGATION OF LEADERSHIP BETWEEN THE STATE AUTHORITY AND THE CIVIL SOCIETY}

Abstract. This article introduces the model of delegation of leadership between the state authority (SA) and the civil society (CS) in order to make state governance effective in conditions of the complex and dynamic environment. The model has to help to identify the degree of involvement of the SA and the CS in leadership of the state according to complexity, uncertainty and dynamics of changes of the environment and the state (system).

Participation of the SA and the CS in state leadership is critical to make the system smart and effective. It requires proper applying of leadership power, changing of leadership styles, and, eventually, the organizational structure based on the situation. The changeable environment requires adaptation of the system and/or shaping of the environment in order to establish equilibrium between the system and the environment. It is possible to do through proper participation of the SA and the CS in the decision-making process (DMP). Together they have to identify roots of the problem, analyze it and make decisions to adapt the system and/ or influence the environment by various synchronized and coordinated activities based on synergy effect.

In the changeable environment, a level of participation of the SA and the CS in the state leadership should be flexible. Complete decentralization or centralization 
with identified rules and regulations may not allow delegating leadership properly between the SA and the CS in order to make the system effective. Moreover, even right combination of the SA and the CS may not provide success because of lack of readiness for their cooperation. It can depend on national culture, a government system, willingness of people to be involved in the leadership process, and other features. Also often only a smaller part of population is active and ready for innovations and change. To collect and educate these people require efforts based on devotion to national values, beliefs, and altruism. However, in a transition period these notions are also changeable and may not present a real "national fundament". All reasons above force finding a practical approach when, where and how to divide leadership power between the SA and the CS in the changeable environment.

Keywords: leadership, state authority, civil society, system, environment, equilibrium, coefficient, thinking, effectiveness.

Постановка проблеми. Технологічний розвиток, глобалізація, посилення комунікації, зростаюча різниця між національними та корпоративними інтересами можуть зробити середовище складним, динамічним та непередбачуваним. Такі умови вимагають пошуку нових підходів керівництва, щоб підтримувати систему адаптивною, гнучкою та ефективною. Ця проблема вимагає дослідження в контексті того, коли, кому і яким чином слід делегувати державну владу.

Аналіз останніх досліджень i публікацій. Постійні дебати щодо численних реформ, пропозицій моделей управління та концентрації на децентралізації не дали відповіді на питання, як ефективно керувати державою [2, с. 5]. У стрімкому мінливому середовищі так зване "нове публічне управління” виникло у 1980-х і на початку 1990-х років “не як реформа традиційного державного управління, а трансформація державного сектору та її вза- ємини з урядом і суспільством" [3, c. 135].

Поєднання ДВ та ГС як двох основних лідерських частин системи $€$ вирішальним для забезпечення ефективного управління в складному та динамічному середовищі. ДВ асоціюється з усіма офіційними організаціями та установами, які формуються за законом. ГС представляє різні неурядові, неприбуткові громадські місцеві, національні та міжнародні організації, приватні фірми та групи. Взаємні організаційні відносини між мережею провайдерів і тими, хто їх керують, є критичними [4].

Децентралізація може розглядатися як делегування повноважень керівництва від ДВ до ГС. Це може полегшити створення "хорошого урядування" [5], що має ефективно працювати в складному середовищі. Проте децентралізація не означає постійного підвищення ефективності системи, особливо в умовах низької готовності до співпраці між ДВ та ГС. Також для складних суспільств “цен- 
тралізація та контроль виникають у міру необхідності обставин” [6, с. 3738]. Тим не менш, абсолютне централізоване керівництво може бути деструктивним у змінному середовищі. Тому, щоб знайти гармонію між ДВ та ГС у складних суспільствах, може знадобитися асиметрична та збалансована децентралізація, яка "не повинна розглядатися як "виграшна" або односторонне відношення" [7, c. 25]. Крім того, зміна середовища вимагає адаптації суспільства. Проте людський фактор природно стабільний, i його зміна вимагає зусиль і часу. Таким чином, в описаних умовах розподіл повноважень керівництва між ДВ та ГС є критичним, щоб ефективно керувати системою в складному та динамічному середовищі.

Мета статті полягає у створенні моделі лідерства для роботи системи в складному та зміненому середовищі на основі належного делегування повноважень керівництва між ДВ та ГС. Багато західних країн знайшли свої шляхи задовольняти людей і підтримувати національні інтереси. Пропонована модель лідерства має вирішальне значення для системи, оскільки довгостроковий пошук моделі управління на перехідному етапі може зменшити ефективність системи або навіть знищити iï.

Виклад основного матеріалу. Застосування філософії державного управління може допомогти зрозуміти суть ефективного управління. “Державне управління як процес $є$ унікальним явищем, яке має значні відмінності в різних країнах світу... Кожна окрема держава, як і кожна людина, є унікальним соціальним явищем" [8]. Навіть у демокра- тичному європейському адміністративному просторі “ми повинні підтримувати широкий діапазон i різноманітність моделей” [9, с. 8]. Тому найважливіша не фіксована модель публічного адміністрування, а підхід, як керувати системою. Модель делегування повноважень керівництва між ДВ та ГС має бути гнучкою через змінюване середовище та особливості різних країн і регіонів, які грунтуються на переконаннях, цінностях та релігіях. Отже, це визначає участь ДВ та ГС в ППР, який повинен встановити баланс системи як задоволення людських потреб.

Потреби можна поділити на фізіологічні потреби, потреби в безпеці, потреби в любові та належності, потреби до уваги та самореалізації [10, c. 64]. Потреби дефіциту - це біологічні потреби, що виникають унаслідок чогось позбавленого. Зростання потреб (соціальних) виникає як бажання особистого росту. Потреби суб’єктивні і залежать від конкретної людини. Вони розвиваються протягом усього життя і мають тимчасову прихильність. Крім того, будь-яка задоволена потреба створює нову. Це дало економіці привід для формулювання закону зростання потреб, а також виражає об’єктивну потребу в зростанні людських потреб (кількісно та якісно) із соціальним та економічним прогресом суспільства.

Для аналізу співвідношень між ДВ та ГС важливо переглянути теоpiï, що описують походження держави та пояснюють суперечність між ними. Відповідно до теорії конфлікту, держава з'явилася через потреби окремих людей і суспільства. Інтеграційні теорії пояснюють, що дер- 
жава виникла через потреби суспільства, а не амбіцій окремих осіб або підгруп [11, с. 15-17].

Координація та напрям окремих частин складних суспільств урядом [6, с. 34] може спричинити напруженість між ДВ та ГС. Держава базується на "поділених інтересах, на пануванні та експлуатації, на примусі, і це насамперед етап боротьби за владу" [11, с. 16-17]. Держава служить для підтримки привілейованої позиції ДВ, підгрунтям для якої в основному $є$ "експлуатація та економічна деградація мас" [12, с. 181-2]. Більш того, керівний орган, який надає товари чи послуги, має силу примусу, що є "неминучою складовою істотної користі” [13, с. 83].

Задоволення потреб формує сукупність інтересів і впливає на поведінку людини. Потреби розширюються, множаться, ускладняються та змінюються не лише кількісно, а й якісно. Потреби генерують мотиви, такі як позапланові мотиви, низькі (побажання, бажання та прагнення), а також високі (інтерес, ідеальна, орієнтація) мотиви. Мотивація - це сукупність мотивів, що визначають поведінку особи. Ініціювання необхідності зміни на основі знань, які можуть переконати і змусити людей змінюватися.

Різниця між очікуваннями та досягненнями може визначати задоволення. Це поняття відносно і може бути різним для людей. Незважаючи на це, можна припустити, що існує певна умова, коли система збалансована та люди задоволені. Визначення цієї умови може допомогти створити універсальну модель, яка визначатиме необхідний рівень делегування повноважень керівництва між ДВ та ГС у будь-якому середовищі та для будь-якій системи.

Теорії та правила лідерства можливо застосовувати для опису відносин між ДВ та ГС як двох суб'єктів керівництва - лідера та підлеглих. ДВ може мати політично амбітних людей, які можуть задовольняти свої амбіції більше, ніж потреби інших. Члени ГС більші за кількістю, але не настільки консолідовані, активні, мотивовані та політично спрямовані як ДВ. Разом ДВ та ГС повинні діяти через ППР, щоб підтримувати національні інтереси та задовольняти людей, впливаючи на систему та/або середовище.

Адаптація системи та/або формування середовища є двома можливими способами для підтримки рівноваги між змінною системою та середовищем. Ступінь їх поєднання пропонуе підхід до відновлення рівноваги на основі доступних способів і засобів. У багатьох випадках адаптація може бути основним способом щоб зробити систему ефективною, незважаючи на ментальні та структурні моделі, які створюються на основі не завжди актуального минулого досвіду.

Для аналізу проблеми ефективного управління важливо бачити систему та середовище як єдине ціле, що породжує розвиток і життя. Подібно до двох конкурентних полюсів, вони існують у їх поєднанні, впливають один на одного, конкурують та протидіють зміні, щоб зберегти свої фізичні та ментальні структури. Зрештою, система та середовище прагнуть зменшити конфлікт між собою шляхом встановлення рівноваги. Фак- 
тично цей процес нескінченний. Встановлена рівновага повинна збалансувати систему та забезпечити їі максимальну ефективність, оскільки система не витрачає додаткову енергію, щоб протистояти середовищу.

Опір є результатом реакції системи на зміну середовища для забезпечення ㄲï балансу. Система захищає власний “центр тяжіння” як одне 3 "першоджерел моральної чи фізичної сили, сили та опору” [14, с.IX], щоб бути захищеними від будь-яких змін. Встановлення нової рівноваги охоплює стратегічний, операційний та тактичний рівні як системний процес розвитку.

Цей процес включає в себе різні заплановані заходи для задоволення системи та середовища або встановлення рівноваги між ними через ППР, що базується на балансі цілей, шляхів та засобів в рамках можливого допустимого ризику (ЦШЗ+Р) [15, с. 87]. Цілі можуть бути переглянуті, щоб підтримувати баланс в рамці ЦШЗ+Р та зберегти систему від руйнування.

Обмеження та кількість різноманітності пов'язані. Збалансована участь ГС у керівництві може забезпечити необхідну різноманітність для боротьби з опором системи, коли потрібні зміни. “Це співвідношення між двома множинами і відбувається, коли різновид, який існує в одному стані, менше, ніж різновид, який існує в іншому” [16, с. 127]. Делегація керівництва від ДВ до ГС може задовольнити цю умову.

Зміни в системі мають вирішальне значення для збереження балансу. Технологічний та економічний розвиток, глобалізація та індивіду- альне зростання роблять систему та середовище складними та змінними. Проблема полягає в тому, щоб контролювати змінну елементів системи та середовища, співпрацювати і створювати “хорошу картину”. Зміна є природною тому, що вона є джерелом енергії, яка базується на фізичних та соціальних сферах людини. Людська соціальна сфера грунтується на соціальних правилах життя, які мають забезпечувати баланс системи упродовж певного періоду. Правила є частиною системи, i їх зміна вимагає застосування інформації, знань та мудрості як найвищого рівня прийняття рішень на основі інтуїції, досвіду та людського задоволення.

Зміна одного 3 елементів соціальної системи може вимагати зміни інших. Одне духовне ціле зв'язує людей. “Все єдине знаходиться в стані рівноваги тоді і тільки тоді, коли кожна частина знаходиться в стані рівноваги в умовах, передбачених іншою частиною” [16, с. 83]. Можна припустити, що рівновага людської системи більше пов'язана з психологічною стороною, коли всі частини загалом поділяють однакові переконання та цінності. Це означає, що основне зусилля може спрямовуватися на культивування подібних цінностей та переконань, які є критичними в ППР.

Філософськи, поняття “все-в-одному просторі” може становити поєднання протилежних ДВ та ГС i пояснити ідею керівництва.

“Духовний принцип визначає весь матеріальний світ усіма його формами i, отже, сам собою вільний від цих форм. Він вільний від простору і часу; початок негайного існування і логіч- 
на сутність - воля і ідея - об'єднані в неї нерозривно; це безумовно єдина і водночас універсальна істота, цілий дух...” [17, с. 142]. Цей дух може відображати національну ідентичність, цінності та переконання. Низька готовність ГС брати участь у процесі керівництва державою та відсутність бажання ДВ делегувати повноваження ГС [18] може показати відсутність єдиного цілого в Україні.

Для підтримки ефективної системи в складному та динамічному середовищі має бути побудована модель організації, яку розглядають, і яка вивчає себе, середовище та робить виправлення на основі реалістичного зворотного зв'язку [19, c. 3-4]. Ця організація є гнучкою, адаптивною і достатньо стійкою для досягнення поставленої мети. Ї̈̈ члени можуть однаково брати участь у ППР та впроваджувати рішення. Подібна співпраця між ДВ та ГС сприяє ефективному прийняттю рішень, що дає можливість правильно адаптувати систему та впливати на середовище. ГС відкриває систему через постійний зворотний зв'язок, навчання та створення умов для критичного, творчого та системного мислення. Ця модель керівництва дозволяє мінімізувати вплив людських упереджень та пасток [20] на ППР.

ГС, “державне управління”, децентралізація та демократія є неминучими уявленнями процвітаючого суспільства, яке здатне швидко вирішити проблеми. Проте лише 32 \% населення України готові взяти участь у вирішенні проблем своєї громади [18, с. 13]. Також тільки $12 \%$ населення добре знають про децентралізацію [18, с. 11]. The majority of population
(67 \%) does not feel real changes because of decentralization [18, c. 1415].

ГС може впливати на політичні амбіції та напрями розвитку системи, але низький рівень участі ГС знижує ефективність управління. В Україні це відбувається через істотні особливості взаємодії між ДВ та ГС, як-то:

1) відсутність розуміння механізму участі та місця ГС в управлінні, незважаючи на побажання ГС брати участь у політичних дискусіях та впровадженні реформ;

2) ГС не довіряє ДВ;

3) ДВ не готова делегувати повноваження ГС;

4) недостатність зв’язку між ДВ та $\Gamma \mathrm{C}$.

В Україні ГС готове брати участь в управлінні, але не розуміє ролі та шляхів участі в процесі керівництва. Оскільки українське суспільство не довіряє політикам, існує тенденція зниження інтересу до державної політики з боку ГС (із 58 до 52 \%) та збільшення кількості байдужих людей до державної політики із 41 до $47 \%$ [21, с. 7]. Таким чином, унаслідок зростаючого розриву між ГС та ДВ система не отримує реалістичного зворотного зв’язку і втрачає ефективність.

Більшість населення України (60 \% у 2015 році та 64 \% у 2016 році) продовжує розглядати необхідну реформу місцевого самоврядування, але лише 24 \% $з$ них вважають це абсолютно необхідним [21, с. 7]. Тобто ГС готове брати участь у політиці України та ДВ повинна делегувати йому частину своєї влади. Крім того, переважна більшість населення, яка, як мінімум, знає про реформи (61%), 
вважає, що це відбувається повільно. Таким чином, реформи не є ефективними, а ППР йде не так. Це можливо пояснити розривами у зворотному зв’язку через брак участі ГС в ППР. Люди не відчувають себе членами однієї команди. Що, своєю чергою, зменшує бажання брати участь і відповідати за процес державного будівництва. Водночас 55 \% населення вважають за необхідне виправлення Конституціï [21, с. 10]. При цьому ступінь свідомості та знань ГС про співпрацю з ДВ у межах демократичної системи є низькою.

Відповідно до “Тіньового звіту" лабораторії законодавчих ініціатив [22] реформа української публічної адміністрації (УПА) показує, що є певний успіх, однак ще є проблеми 3 реалізацією реформ. Взагалі модель УПА поки що не є вивчаючою організацією. В умовах змінного та динамічного середовища УПА як система не $є$ ефективною і не може конкурувати $з$ розвиненими європейськими або американськими моделями публічного адміністрування.

Це не означає, що УПА на неправильному шляху i розвитку. Це просто процес пошуку і тестування відповідної моделі керівництва та ii. структури для України. Проте існують очевидні прогалини в роботі через відсутність системного підходу до розуміння проблеми. Немає консолідованого політичного керівництва, довгострокової стратегічної мети, наявний розрив між ППР i процесом планування, слабка законодавча система для підтримки реформ публічного адміністрування, слабкі комунікація, брак професіоналів, недостатній рівень комп'юте- ризації, слабкий зворотний зв'язок та механізм оцінки. Все наведене робить УПА неефективним. Таким чином, можна помітити, що УПА як система слабка і не може ефективно працювати та підтримувати належно національні інтереси, особливо в конкурентних умовах складного та змінного середовища.

Застосування поняття “ентропія” може пояснити взаємозв’язок між системою та середовищем для побудови моделі ефективного керівництва. Ентропія може розглядатися як характеристика різноманітності системи, яка визначається імовірностями реалізації станів і досягає максимуму при рівномірному розподілі (максимальне різноманіття, коли будь-який стан може бути реалізований 3 однаковою імовірністю), а мінімум - коли будь-який стан реалізується 3 імовірністю, рівною 1. При цьому керування полягає в такому перетворенні сукупності станів, коли зменшуються імовірності деяких (небажаних) контрольованих станів і зростають імовірності інших (бажаних) станів, що забезпечує зниження ентропіі. Відповідно до закону необхідної різноманітності [16], це може бути досягнуто шляхом збільшення різноманітності системи, що здійснюється за умови однозначного керівництва. Таким чином, зростання складності зумовлене різноманітністю системи за умови одного керівництва. ГС може забезпечити різноманітність, а ДВ - єдине керівництво.

Відкрита система має тенденцію до зменшення ентропії через взаємодію із середовищем, отже, до покращення процесу прийняття рішень. 
Залежно від рівня початкової ентропії та ефективності підходу щодо прийняття рішень ентропія зменшується в часі [23]. Зовнішнє середовище має певний рівень залишкової ентропії або невизначеної інформації, необхідної для ППР. Початок ППР відповідає високому рівню інформаційної ентропії.

В умовах складного та динамічного середовища гнучке керівництво може полегшити створення вивчаючої організації, яка відкрита для адаптації через підвищений рівень ентропії. Ця організація має найвищий рівень демократії, заснований на “публічному управлінні" та децентралізації, коли кожний має рівний голос. Це полегшує розвиток знань, а отже, здатність перегляду застарілих ідей та сприйняття, оскільки знання підтверджують необхідність змін.

"Публічне управління" представляє собою тип лідерства за участю більшості на основі демократії. Однак неконтрольована демократія може створити анархію, коли система втрачає свою функціональність. Зміни середовища впливають на систему i, зрештою, змінюють іiї структуру. У цьому випадку досягнення певного критичного рівня може вимагати централізованого (авторитетного) типу лідерства, щоб швидко приймати життєво важливі рішення, щоб зберегти функціональність системи та виконати місію. Таким чином, процес керівництва є гнучким і залежить від середовища.

Автор вважає, що ефективне керівництво системою означає створення вивчаючої організації, яка буде підтримувати рівновагу між системою та середовищем та досягне встанов- лених цілей. Правильне керівництво системою вимагає швидкої реакції на зміну на основі зворотного зв'язку, впливу на політичні амбіції, швидкість ППР та реалізації рішення. Досягти цього можна завдяки гнучкому делегуванню влади керівництва між ГС та ДВ. Це може вимагати структурних змін, перегляду цінностей, переконань та застарілих ментальних моделей [24], оскільки у новому середовищі вони більше не підтримують ефективних рішень. Навчання та знання мають змусити людей до зміни через їхню участь у ППР.

Коефіцієнт динамічної рівноваги $\left(K_{e q}\right)$ визначає рівень рівноваги між системою та середовищем [25, с. 8]. Своєю чергою, він може визначити ступінь делегування повноважень керівництва між ДВ та ГС для поліпшення ППР та підтримки балансу системи. Цей коефіцієнт має відповідати оптимальному коефіцієнту динамічної рівноваги $K_{\text {eq opt }}[24$, c. 216], який забезпечує максимально досяжну ефективність системи в умовах змінного середовища.

ДВ представляє та головним чином захищає існуючу систему управління. ГС змінює систему, щоб задовольнити потреби людини. Разом вони повинні пропагувати національні інтереси. Ступінь участі ДВ та ГС у процесі керівництва зазвичай відрізняється в регіонах або областях однієї країни через особливості цінностей, переконань, сприйняття, культури, традицій, правил, норм, географічних та економічних умов, діалектів тощо.

Якщо рівновага зруйнована з різних причин, ситуація стає хаотичною і система починає шукати нову струк- 
туру (порядок). Це як “головоломка”, коли людина, яка приймає рішення, повинна правильно зібрати частини головоломки і створити “картинку", що задовольнить систему та середовище. Це свого роду торги та переговори, під час яких використовуються різні способи та засоби, щоб отримати найкращий результат для кожної сторони. Існує найбільш вдала комбінація переговорів. Однак, оскільки система та середовище є змінними для підтримки цієї комбінації, потрібно постійно керувати системою на основі прийняття рішень.

Система коливається під впливом середовища. Якщо коливання системи відповідає коливанням середовища, вони можуть викликати резонанс та синергічний ефект. Крім того, у фізичній системі існує стільки резонансних частот, скільки є ступенів свободи. Це може потребувати розуміння один одного через відкритість системи та спілкування. Створення резонансу може означати зміну чогось. Резонанс може бути силою змін, яка створює нову структуру системи через руйнування за- старілої. Це є результатом високої частоти коливань між системою та середовищем або їх "взаємної згоди” бути на однаковій “хвилі” та розуміти один одного.

Затримка реакції системи на зміну середовища $(\Delta \mathrm{T})[26$, с. 179$]$ визначає iï ефективність. Це може спричинити конфлікт як відсутність поступової або "м'якої" адаптації на основі відкритості системи та реалістичного зворотного зв'язку. Відповідна участь ДВ та ГС у ППР зазвичай впливає на зменшення $\Delta \mathrm{T}$. Вирішення зростаючого конфлікту вимагає збільшення частоти коливань ДВ $\left(F_{s a}\right)$ та ГС $\left(F_{c s}\right)$. Взаємодія між ДВ та ГС, як продукт конвергентних та дивергентних процесів [27] (рис. 1), повинна генерувати необхідні рішення для вирішення проблем.

Точки А і В (рис. 1, 2) показують дивергентні та конвергентні процеси мислення. На початку ППР амплітуда коливань функцій $F_{s a}$ та $F_{c s}$ висока. До кінця ППР конвергентні та дивергентні процеси зближуються, i зрештою рішення приймається в точці їх сходження.

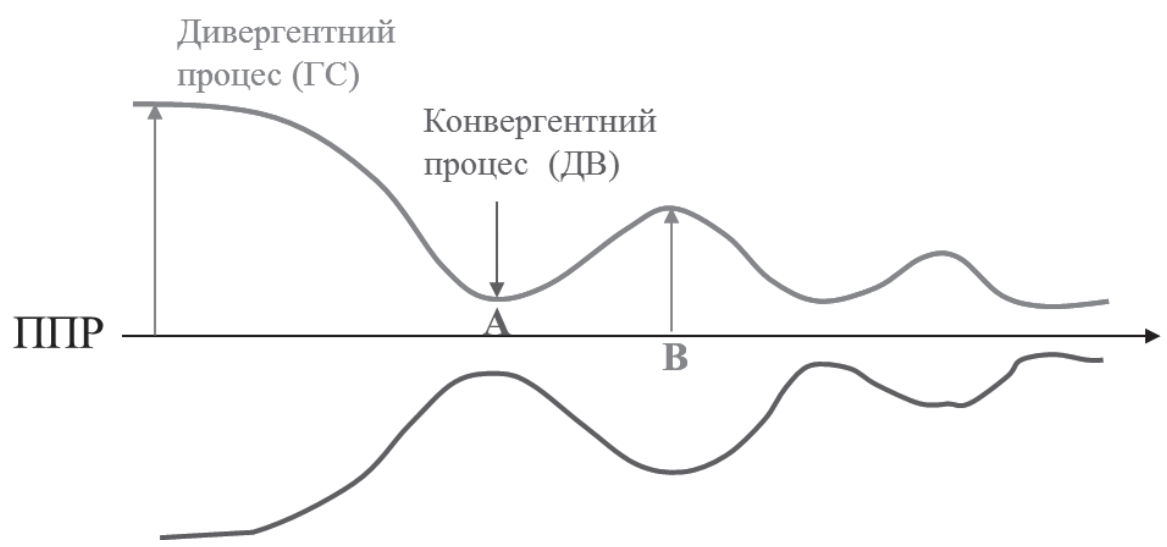

Рис. 1. Дивергентні та конвергентні взаємодії в ППР між ДВ та ГС Джерело: створено автором. 
Рівень участі членів системи у негативному та позитивному зворотному зв'язку може визначити адаптивність системи. Процес відображає негативний зворотний зв'язок, як критичне мислення в ППР, та дивергентний процес - позитивний зворотний зв'язок, як креативне мислення. Системне мислення має поєднувати парадоксально різні ДВ з ГС. Загалом це процес лідерства 3 певним рівнем делегування повноважень один одному.

В умовах змінного середовища $K_{e q}$ дорівнює рівню делегування лідерської влади та $K_{e q}=f\left(F_{s a}, F_{c s}\right)$. Таким чином, співпраця між ДВ та ГС на основі знань буває критичною для вчасного реагування на зміни середовища. Це може виступати ключовим поняттям для побудови моделі вивчаючої організації, яка дає можливість знайти "новий порядок 3 хаосу” без конфліктів. Отже, виходячи 3 цього, можна створити модель керівництва, яку застосовують до будь-якого рівня управління: парламент з протилежними партіями, регіони, місцеві громади з різними інтересами та ін.

ГС має певні амбіції та потреби у зростанні. Їх реалізація означає досягнення $K_{\text {eq opt }}$, але на новому рівні розвитку. Це безперервний процес розвитку системи, коли наступне зростання може знов порушити рівновагу між системою та середовищем. Частота коливань системи $\left(F_{s}\right)$ та середовища $\left(F_{\text {env }}\right)$ може бути обмежена. Коли вони досягнуть певного можливого максимуму, систему можна змінити для того, щоб знову відновити рівновагу або досягти $K_{\text {eq opt }}$.
Оцінка системи може допомогти визначити $K_{\text {eq opt }}$. Mipa ефективності (ME) відповідає на запитання - чи правильно діє система? Miра продуктивності (МП) відповідає на питання - чи правильно система це робить [28, с. 15-2]? МЕ, як рівень реалізації національних (регіональних) цінностей та переконань майбутнього бачення та МП, як рівня життя, доходів, процвітання та безпеки, можуть визначати $K_{\text {eq opt }}$. ДВ та ГС встановлюють МЕ та МП як задоволення людей, засноване на реалізації їхніх побажань, переконань, цінностей та підтримання інших національних інтересів. Якщо немає задоволення, рішення є неправильним. ME та МП повинні підтримувати цю умову. Наприклад, якщо створені ME та МП не забезпечують бажаного та реалістичного рівня життя, люди можуть вважати їх неправильним.

ME та МП нерідко відрізняються для систем через різні причини. ME залежить від середовища, стану системи (стабільного, нестабільного), положення системи в рамках “часу, простору та спроможності”, взаємного впливу між системою та середовищем. МП залежить від довіри, єдності зусиль, спільних інтересів, патріотизму, відкритості тощо.

Рівень задоволеності людини (Lhs), як різниця між очікуваннями та результатами, може визначити $K_{\text {eq opt }}$ для системи. Задоволення людини є відносним поняттям, яке грунтується на національних рисах, культурі, сприйнятті, менталітеті тощо. У будь-якому випадку, воно визначає оптимальну рівновагу між системою та середовищем: 
$K_{\text {eq opt }}=f($ Lhs $)$. Lhs можуть бути оцінені МЕ та МП за допомогою ціннісних показників.

Задоволення ДВ та ГС визначає баланс системи. Можливо припусти-

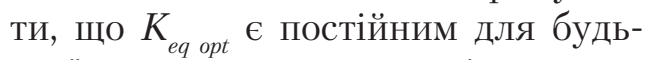
якої системи та умов, оскільки це є характеристикою іiї балансу. Наприклад, регіони однієї країни відрізняються через середовище (географічне розташування, клімат, економічна орієнтація, сусіди) та власні характеристики (релігії, мовні діалекти, традиції та правила), але щоб бути збалансованою регіональна спільнота має встановити $K_{e q ~ o p t}$. Також система може досягти $K_{e q c t}^{e q ~ o p t}, K_{e q \min }$ та $K_{e q \max }$ в яких вона може знизити ефективність та досягти точок біфуркації (змін). Модель делегування повноважень керівництва має сприяти успішному керівництву системою на основі чотирьох ключових точок: $K_{\text {eq min }}, K_{\text {eq crt }}, K_{\text {eq opt }}$ та $K_{\text {eq } \max }[29$, c. 180].

Модель керівництва включає ДВ з державними установами та ГС з різними недержавними організаціями. В ідеалі всі гравці повинні працювати разом, щоб отримати синергетичний ефект. Лідер має вести і синхронізувати їх. ДВ та ГС є частиною процесу керівництва. ДВ повинна відчувати ГС та ГС повинно розуміти ДВ і національні інтереси. Обидва повинні працювати разом через одну мету підтримувати/покращувати рівень життя (національні інтереси). ДВ та ГС є частинами однієї системи, яка повинна швидко реагувати на будьякі зміни в системі та/або середовищі. Для цього система повинна діяти 3 певною частотою коливань $\left(F_{s}\right)$ до коливань середовища $\left(F_{\text {env }}\right)$. ДВ та ГС певною мірою $\left(F_{s a}, F_{c s}\right)$ коливаються та разом представляють коливання системи $\left(F_{s}\right)$.

Частота коливань $F_{s}\left(F_{s a}, F_{c s}\right)$ та $F_{\text {env }}$ може визначати підхід до вирішення проблем. На основі $F_{s a}$ ДВ повинна змінювати лідерська силу, грати із стилями керівництва, а згодом - змінити структуру системи [1, c. 72]. $F_{c s}$ більше пов'язана з $F_{\text {env }}$. ГС має реагувати на зміни середовища через ДВ. Якщо $F_{\text {env }}$ висока, ГС відіграє важливу роль в реагуванні на зміни середовища на основі децентралізації. Це циклічний процес реакції на зміну Env $\rightarrow$ ГС $\rightarrow$ ДВ.

Можна припустити, що функції ДВ та ГС мають форму відхилення та певну нормальну лінію (див. рис. 2). Нормальна лінія пов'язана 3 балансом та ефективністю системи. Відповідне використання комбінації ДВ та ГС може змістити нормальну лінію системи на інший рівень, щоб реагувати на зміни середовища. Нормальна лінія зазвичай відповідає певній структурі системи.

Нормальне (оптимальне) керівництво системою $\left(S_{\text {nот }}\right)$ означає piвень комбінації ДВ та ГС у даному середовищі, яке повинно забезпечувати необхідну ефективність системи та відповідати $K_{\text {eq opt }}$, коли система є збалансованою та ефективною. $S_{\text {norm }}$ може перейти до авторитарного типу лідерства $(S 1)$, коли ДВ є домінуючим або демократичним типом $(S 2)$, коли ГС відіграє головну роль (див. рис. 2). Різні позиції моделі керівництва можуть залежати від середовища та швидкості її зміни. Можна припустити, що сума загальної влади ДВ і ГС дорівнює 1 (ДВ + ГС $=1)$.

Керувати рівнем участі ДВ та ГС є вирішальним для того, щоб відпо- 


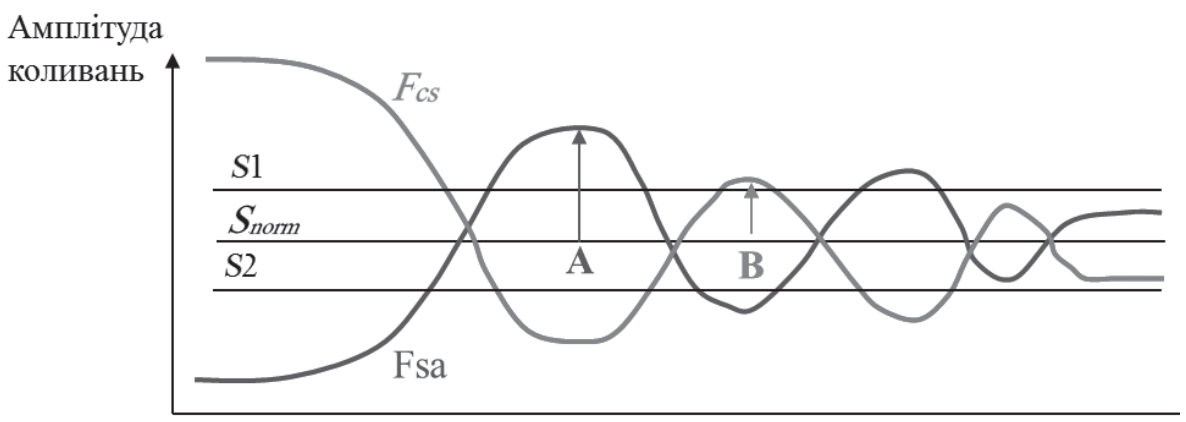

Рис. 2. Баланс лідерської влади між ДВ та ГС Джерело: створено автором.

відно реагувати на змінне середовище. Однак обидві сторони повинні збалансувати і підтримувати систему на рівні $S_{\text {пот }}$. Цей рівень забезпечує найефективнішу функціональність системи. Означену позицію слід очолити, доки система з поточною структурою та технологічним розвитком не стане застарілою. Це відповідає зміні структури системи як третій рівень лідерської реакції [1, с. $72]$. Нова $S_{\text {потm }}$ з новими $S 1$ та $S 2$ означає зміщення системи на нові технологічні та структурні рівні.

Оптимальна комбінація між участю ДВ та ГС забезпечує максимально можливу ефективність системи. Це може основуватися на таких умовах середовища та системи, як геополітичне розташування, економічний стан, культура, національне сприйняття тощо. Впровадження поняття рівня участі ДВ $(L s a)$ та ГС $(L c s)$ у процесі державного керівництва може допомогти проаналізувати ефективність управління.

ДВ представляє централізовану владу, ГС - децентралізовану. Частка їх взаємної участі може визначатися коефіцієнтом участі $-C p$. Таким чином, $C p=L c s / L s a$. Якщо $C p \rightarrow 1$, система є демократичною i теоретичною, коли $C p=1$, лідера взагалі немає. Якщо $C p \rightarrow 0$ домінуе авторитарний лідер. Можна погодитися $з$ тим, що за умови $0,5 \leq C p<1$ система є демократичною, а коли $0<C p<0,5$ - система авторитарна.

Необхідність відкриття системи для адаптації та іiі контролю, одночасно створює парадокс. У цій ситуації головна роль може належати керівництву та розумінню, де, коли і хто повинен керувати системою. Таким чином, завдання полягає в тому, щоб підтримувати $K_{e q}$ вибір на основі відповідного $C p$, який має бути гнучким, а отже, різним. Це означає, що створення довготривалої децентралізації чи централізації не забезпечуе високої ефективності системи.

Найкращий $C p$ має забезпечити максимальну ефективність системи, коли $K_{e q}=K_{e q ~ o p t}$. Цей стан визначає рівень необхідного $C p$ для системи в поточному середовищі. Таким чином, $C p$ залежить від середовища та $K_{e q}$ У певний момент. Отже, рівень ефективності системи (Lsef) є функцією $K_{\text {eq opt }}$, а $K_{\text {eq opt }}-$ це функція $C p$. Таким чином, Lsef $=$ $=f\left(K_{\text {eq opt }}(f(C p))\right.$.

Тому “публічне урядування” це не чиста участь ГС, коли $C p=1$ або вза- 
галі немає ДВ $(L s a=0)$. Насправді, це ідеальна модель вивчаючої організації, яка постійно адаптується до середовища. 3 одного боку, система може змінитися або зникнути під час адаптації. 3 іншого - це може допомогти зберегти систему під сильним впливом середовища. Якщо завдання полягає у збереженні функціональності системи, ДВ та ГС, обидва, повинні брати участь у процесі управління на основі збережених переконань, цінностей, ідеології та патріотизму. Якщо завдання полягає в адаптації системи, переконання та цінності можуть переглядатися.

Для прийняття рішення, яке задовольнить регіональні та національні інтереси, ДВ та ГС мають брати участь у ППР. Метою керівництва $€$ встановлення $C p$ на основі ситуації або сприятливого моменту в межах "часу, простору та спроможності". Завдання полягає в тому, щоб зберегти $K_{\text {eq opt }}$, який забезпечить функціональність системи шляхом своєчасного здійснення змін. Правильний $C p$ повинен збалансувати ЦШЗ + $\mathrm{P}$ в ППР. Регулювання $C p$ є гнучким процесом, який потребує кваліфікованих лідерів на місцевому, регіональному та урядовому рівнях.

Щоб зробити управління ефективним, може знадобитися:

для ГС:

1) створити/вдосконалити модель участі ГС у прийнятті рішень у державі;

2) пояснити важливість участі ГС у процесі керівництва та залучення ГС як рівноправного учасника процесу;

для ДВ:

3) бути готовим делегувати частину своїх повноважень ГС;
4) відкрити лінії зв'язку з ГС та заслужити довіру з боку ГС шляхом позитивних результатів;

5) визначити рівень участі ДВ та делегування повноважень для задоволення ГС та встановлення балансу системи (збереження національних інтересів).

Усвідомлення ситуації, відкритості системи та оцінка результатів визначає здатність системи до змін. Зміщення групової ментальності до індивідуальних цінностей збільшує роль людини. Наприклад, радянський менталітет захищає колектив і зменшує індивідуальну роль. Бажання людей лідирувати визначає рівень делегування повноважень керівництва між ДВ та ГС. Таким чином, нова демократична модель управління може грунтуватись на зміні людського сприйняття, ментальності та культури через пояснення важливості участі ГС в управлінні.

ДВ може бути не готова делегувати свою владу ГС, при цьому ГС не має достатніх знань і розуміння, як правильно її використовувати. Також однією з проблем є відсутність довіри між ДВ та ГС, оскільки вони не виглядають однаково. Ці відносини можуть визначати соціальну культуру. Застарілі ментальні моделі не дозволяють встановлювати новий культурний формат, щоб вчасно адаптувати систему.

Змінити частку участі ДВ та ГС у керівництві складно через інерцію системи. Належний соціальний

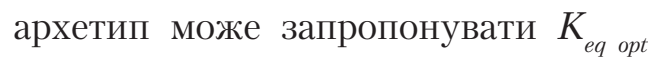
як продовження попереднього архетипу, але на новому рівні розвитку. Національний соціальний архетип 
формується на основі геополітичного розташування системи. Зміна середовища зумовлює адаптацію системи та сусідніх систем та їх архетипів. Ця системна комплексна зміна означає трансформацію усіх видів соціальних артетипів для забезпечення рівноваги простору як поєднання системи із середовищем, коли $K_{\text {eq }} \rightarrow K_{\text {eq opt }}$.

Соціальний архетип має сприяти готовності ГС взяти участь у керівництві та ППР. Новий тип соціального архетипу повинен бути розроблений у процесі вивчення середовища та системи. Таким чином, здатність системи до навчання $\left(S_{a t l}\right)$ може бути характеристикою системи, яка також визначає ефективність системи. $S_{a t l}$ визначає, наскільки розумною є система та $C p$, адже система визначає, коли, хто і де повинен впливати на неї, щоб підтримувати $K_{\text {eq opt }} . S_{\text {atl }}$ визначає, наскільки система є близькою до моделі навчальної організації. Рівень участі ГС у керівництві, відкритість системи та зворотний зв'язок можуть визначати $S_{a t l}$. Ці характеристики системи визначають соціальний архетип, організаційна культура, структура та лідер. Таким чином, Lsef = $=f\left(K_{\text {eq opt }}\left(C p, S_{\text {atl }}\right)\right)$.

Підвищення $S_{\text {atl }}$ означає виховання системи як ДВ, так і ГС, використовуючи різні підходи, як-то: засоби масової інформації, розроблення високих стандартів, інновації, курси, побудову моделі “єдиний уряд”, підвищення особистої відповідальності через створення простору участі в керівництві через соціальні мережі, застосування нових комп'ютерних програм та веб-мереж.
Це створює культуру навчальної організації 3 негайним зворотним зв'язком, виправленнями та адаптацією. Крім того, система повинна позитивно ставитися до навчання. Тобто керівництво та члени системи мають отримувати задоволення від цього процесу та бути творчими з баченням та відкритістю для інновацій. Незважаючи на делегування повноважень керівництва, лідер залишається важливим.

Крім того, $C p$ може відповідати певній комбінації конвергентних та дивергентних процесів у мисленні, що грунтується на зміні та ускладненні середовища і системи. Наприклад, складна ситуація вимагає дивергентного процесу або підвищення $C p$. Брак довіри між ДВ та ГС створює непорозуміння. Знаходження спільної мови та відповідної моделі їх відносин є питанням лідерства, заснованого на соціальному архетипі, національній та організаційній культурах. Це формує модель державного лідерства, яка може збільшити або зменшити $S_{a t t}$.

Знання та освіта для ГС можуть покращити соціальну свідомість, щоб брати участь у державному управлінні. Освітні центри, установи, засоби масової інформації, курси для ДВ та ГС можуть збільшити їх співпрацю, а отже, ефективність управління на основі чесності та прозорості. Це робить систему життєздатною та конкурентоспроможною на основі творчості, знань, здібностей та навичок кожного члена суспільства. В ідеалі це може створити синергетичний ефект розвитку спільноти на основі одного духу, свободи, взаємної підтримки та бажання працювати разом. 
Щоб зробити систему ефективною, потрібна їі своєчасна зміна. Найважчим є зміна ментальних моделей, які впливають на рішення. Вони $є$ стабільними, довготривалими концепціями, що грунтуються на переконаннях та цінностях. Здатність відмовитися від прийнятих норм в умовах змінного середовища є критичною. Люди переглядають ментальні моделі та в більшості випадків відмовляються від використання попереднього досвіду. Наприклад, американська держава як бізнес-система надає безстресовий підхід до змін норм, оскільки вони більше не підтримують ефективність системи. Все спрямоване на підтримку ефективності системи (внутрішня та зовнішня політика держави).

Змінити переконання та цінності в Україні може бути складніше через традиційну консервативну культуру, менталітет та достатньо закриту державну систему. Незважаючи на це, технологічні інновації сприяють зміні середовища та розвитку системи. Це змушує змінювати норми, поведінку та комунікацію. У процесі спілкування соціальні групи адаптують власний словниковий запас, емоції, жести, зовнішність, щоб бути в рівновазі із сучасним глобалізованим міжнародним простором. Це схоже на створення нової спільної мови. Процес може впливати на сприйняття, цінності та переконання.

Крім того, в умовах відкритого інформаційного простору, електронне управління та уряд [30] створюють умови для е-демократії. "Електронне управління - це використання інформаційних та комунікаційних технологій для підтримки належного уряду” [31]. Це робить систему відкритою та адаптованою до процесу навчання, а також впливає на відносини між ДВ та ГС і децентралізуе систему. Також реальний лідер може бути замінений віртуальним, який може бути сформований ДВ та ГС у просторі Інтернету через мережі соціальних комунікацій.

Лідерський процес $є$ питанням ефективності системи на основі балансу між мінімальними та максимальними обмеженнями 3 тим, щоб певною мірою відкрити або закрити систему. Це означає зберегти систему, що перебуває на краю без порядку та безладу, для адаптації зі збереженням функціональності системи. Керівництво держави повинно застосовувати належну лідерську владу, змінювати стилі керівництва та структуру системи. Інакше кажучи, якщо регіон вимагає централізованої влади та сильного лідера або децентралізованої влади, це треба визнати та втілити в межах системи, а також підсистем (регіонів). Незважаючи на це, у разі підвищеної складності середовища ДВ та ГС мають бути готові до співпраці, заснованої на делегуванні повноважень керівництва у потрібний час і належним чином.

Модель делегування керівництва між ДВ та ГС (див. рис. 3) становить алгоритм керування системою до таких умов: 1) підтримка балансу системи на основі забезпечення рівноваги між системою та середовищем (для підтримки $K_{\text {eq opt }}$ ); 2) досягнення системою встановлених цілей. Якщо одне з цих умов не задовольняється, лідер, грунтуючись на трьох умовах [1) $K_{e q} \rightarrow K_{e q \text { min }}$; 2) $K_{e q} \rightarrow K_{e q c r} ;$;) $K_{e q} \rightarrow K_{e q \max }$, має де- 
легувати лідерську владу між ДВ та ГС, змінювати силу лідерської влади, стилі керівництва, структуру системи і завжди збільшувати $S_{a t l}$. Також, щоб збалансувати цілі, шляхи та засоби в рамках можливого допустимого ризику, дуже важливо успішно керувати системою. Досягнення системою $K_{\text {eq opt }}$, як ключове поняття алгоритму, може бути визначено соціальним задоволенням на основі $\mathrm{ME}$ та МП.

Висновки. Запропонована модель делегування керівництва між ДВ та ГС може сприяти підвищенню ефективності державного управління. Для ефективного управління необхідно задовольнити дві умови (рис. 3) в рамках коефіцієнта динамічної рівноваги $-\left[K_{\text {eq min }}-\right.$
$\left.-K_{\text {eq crt }}-K_{\text {eq opt }}-K_{\text {eq max }}\right]$. По-перше, це потребує чіткого розуміння системи, середовища, проблеми та цілей системи. По-друге, ППР вимагає участі як у ДВ, так і в ГС, але фіксований рівень централізації чи децентралізації, зазвичай, не може бути ефективним. Рівень участі в державному керівництві $(C p)$ та децентралізація може залежати від умов. По-третє, держава як система повинна бути схожою на модель навчальної організації з гнучким лідерством, заснованим на взаєморозумінні між ДВ та ГС. Це означає, що система повинна розуміти необхідність, час та ступінь делегування державної влади між ДВ та ГС. Своєю чергою, ДВ та ГС повинні активно брати участь у публічному управлінні, щоб відкрити систему

\section{1) $K_{\text {eq }} \rightarrow K_{\text {eq } \min }:$ \\ - делегуй владу ГС, встановлюй умови

$$
0,5 \leq C p<1 ;
$$

- змінюй структуру системи (на основі $F_{S}$ $\left(F_{s a}, F_{c s}\right)$ та $\left.F_{\text {env }}\right)$.

\section{2) $\mathrm{Keq} \rightarrow \mathrm{Keq}$ crt $:$}

- грай з $C$, змінюючи лідерську потужність, стилі керівництва.

\section{3) $K_{\text {eq }} \rightarrow K_{\text {eq } \max }:$}

- концентруй владу ДВ, встановлюй умови

$$
0<C p<0,5 \text {. }
$$

Завжди: підвищуй $S_{a t l}$; Балансуй ЦШЗ + P (переглядай изілі).

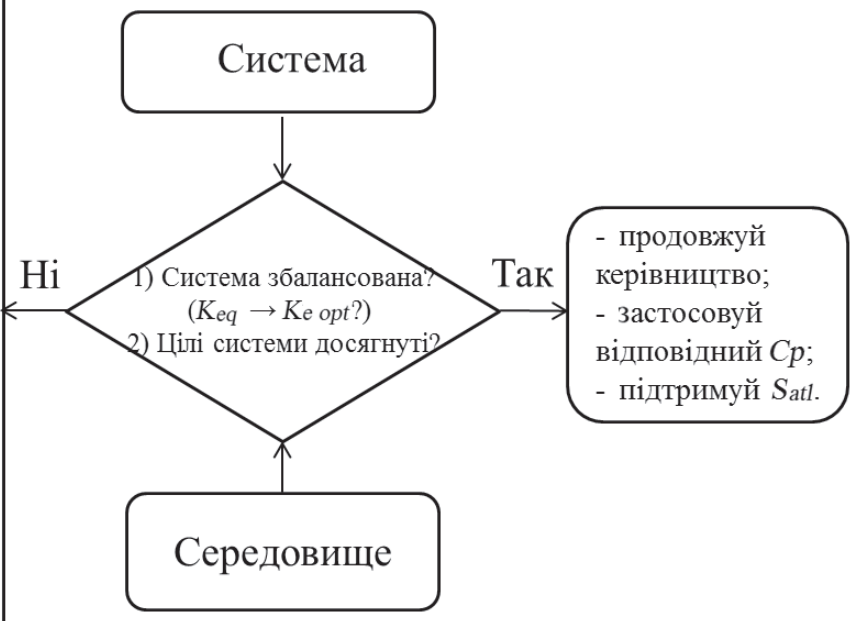


достатньо зворотного зв'язку та постійного спілкування, заснованого на чітко оголошених та адаптованих до середовища національних цінностях, переконаннях, єдності зусиль та цілей.

\section{СПИСОК ВИКОРИСТАНИХ ДЖЕРЕЛ}

1. Naplyokov Y. V. (2011). "Increasing unit effectiveness in a dynamic environment by implementing a leadership mathematical model”. Master's Thesis, U.S. Army Command and General Staff College, CARL, Fort Leavenworth, KS 66027-2301, USA.

2. Pollitt Cristopher, Bouckaert Geert. (2011). Public management reform. A Comparative Analysis - New Public Management, Governance, and the Neo-Weberian State, third edition. New York: Oxford University Press.

3. Hoos J., Jenei G., Vass L. (2003). Public Administration and Public Management: Approaches and Reforms, In: Public Policy in Central and Eastern Europe: Theories, Methods, Practices, (eds.) M. Potucek, L. T. Leloup, G. Jenei, L. Varadi, NISPAcee.

4. Milward H. B., Provan K. G. (2000). Governing the Hollow State. Journal of Public Administration Research and Theory 10 (2): 359-379.

5. Attila Agh. (2013). Europeanization of Public Administration in Eastern and Central Europe. Croatian and Comparative Public Administration, p. 739-762.

6. Tainter Joseph A. (1988). The nature of complex societies, New York: Cambridge University Press.

7. Utomo Tri, Widodo W. (2009). Balancing decentralization and deconcentration: emerging need for asymmetric decentralization in the unitary states. Graduate School of International De- velopment Nagoya University. Jahan. Discussion Paper № 174.

8. Korzhenko V. V. (2016). "The phenomenon of philosophyas "Practical wisdom” of state governance”, Theory and Practice of Public Administration, vol. 2 (53), p. 1-7.

9. Geert Bouckaert, Mzia Mikeladze. (2009). The NISPAcee Journal of Public Administration and Policy, vol. I, № 2, winter 2008/2009.

10. Maslow A. H. (1943). "A theory of human motivation." Psychological Review. 50 (4), p. 370-396.

11. Lenski G. E. (1966). Power and Privilege. A Theory of Social Stratification. New York: McGraw-Hill.

12. Childe Gordon V. (1951). Social evolution. Publisher: Henry Schuman. Tianer Joseph, A. 2003. The nature of complex societies, Cambridge, UK: Cambridge University Press.

13. Haas Jonathon (1982). The Evolution of the Prehistoric State. Columbia University Press, New York.

14. Strange J. (2005). Center of Gravity and Critical Vulnerabilities. Quantico, VA., USA, Marine Corps University, Defense automated printing service center [E-Reader Version]. Retrieved from: http://jfsc.ndu.edu/Portals/72/ Documents/JC2IOS/Additional Reading/3B_COG_and_Critical_ Vulnerabilities.pdf

15. Bielska T. V., Naplyokov $Y . \quad V$. (2017). Maximum allowable risk in decision-making process. // Public Management. № 7 (2). p. 76-88. Retrieved from http://vadnd.org.ua/ app/uploads/2017/07/Англ.pdf

16. Ashby Ross W. (1957). An Introduction to Cybernetics. Second Impression. London: Chapman \& Hall LTD.

17. Solovyov V. S. (1873-1877). Kryza zakhidnoi filosofii [The crisis of Western philosophy], 2nd ed, Book Society Prosvita. St. Petersburg, Russian Empire. 
18. Sidoruk O. (2016). Detsentralizatsiia: rezul'taty, vyklyk i perspektyvy [Decentralization: Results, Challenges and Prospects], Analytical report. Democratic Initiative Foundation named after Ilk Kucheriv. Kyiv, Ukraine.

19. Senge P. M. (2006). The Fifth Discipline: The Art \& Practice of the Learning Organization. New York, N.Y.: Doubleday.

20. Gerras Stephen J. (2008). Thinking Critically about Critical Thinking: A Fundamental Guide for Strategic Leaders, Planner's Handbook for Operational Design.

21. Kyiv International Institute of Sociology. (2016). Decentralization and local self-government reform: results of the second wave of sociological research, Analytical report. December 2016.

22. Laboratory of legitimate initiatives. (2018). Shadow Report on Reforms of state service and PA in Ukraine in 2017. U.S. Aid. Kyiv.

23. Katrenko A. V., Parsternak O. V. (2015). "Theproblem of optimality in thetheory and practice of decision-making", Visnyk Natsional'noho universytetu “L'vivs'ka politekhnika”, vol. № 829, p. 359-373.

24. Naplyokov Y. V. (2018). "Changing of mental models for effective decisionmaking" // Public Management № 1 (11). p. 189-206. Retrieved from: http://vadnd.org.ua/ua/collection/

25. Naplyokov Y. V. (2014). "An Algorithm for Maintaining Dynamic Equilibrium to Achieve Strategic Goals.” Master's Thesis, U.S. Army War College, Carlisle Barracks, Pennsylvania 17013, USA.

26. Naplyokov Y. V. (2018). The archetypal foundations of value choice in the process of adaptation to the modern society // Public Management. № 4 (14). p. 171-183. Retrieved from: http://pub-management.com/index. php/about/article/view/109/94
27. Allen C.D. (2012). "Creative Thinking for Individuals and Teams." An essay on creative thinking for military professionals. U.S. Army War College. Retrieved from: http://www.au.af.mil/ au/awc/awcgate/army-usawc/allen creative_thkg_sr_ldrs.pdf

28. Headquarters, Department of the Army (2015), FM 6-0, Commander and Staff Organization and Operations. Washington, DC, USA, DOI: 104216001.

29. Bernhard I. (2013). E-government and E-governance - Swedish Case Studies with Focus on the Local Level. Stockholm, Sweden: KTH, Royal Institute of Technology. Available at: https://www.diva-portal.org/smash/ get/diva2:663249/FULLTEXT01.pdf

30. HeeksR.(2001).Buildinge-Governance for Development: A Framework for National and Donor Action. E-Government Working Paper Series, № 12. Available at: http://unpan1. un.org/intradoc/groups/public/documents/NISPAcee/UNPAN015485. pdf

\section{REFERENCES}

1. Naplyokov Y. V. (2011). "Increasing unit effectiveness in a dynamic environment by implementing a leadership mathematical model". Master's Thesis, U.S. Army Command and General Staff College, CARL, Fort Leavenworth, KS 66027-2301, USA.

2. Pollitt Cristopher, Bouckaert Geert. (2011). Public management reform. A Comparative Analysis - New Public Management, Governance, and the Neo-Weberian State, third edition. New York: Oxford University Press.

3. Hoos J., Jenei G., Vass L. (2003). Public Administration and Public Management: Approaches and Reforms, In: Public Policy in Central and Eastern Europe: Theories, Methods, Practices, 
(eds.) M. Potucek, L. T. Leloup, G. Jenei, L. Varadi, NISPAcee.

4. Milward H. B., Provan K. G. (2000). Governing the Hollow State. Journal of Public Administration Research and Theory 10 (2): 359-379.

5. Attila Agh. (2013). Europeanization of Public Administration in Eastern and Central Europe. Croatian and Comparative Public Administration, p. 739-762.

6. Tainter Joseph A. (1988). The nature of complex societies, New York: Cambridge University Press.

7. Utomo Tri, Widodo W. (2009). Balancing decentralization and deconcentration:emerging need for asymmetric decentralization in the unitary states. Graduate School of International Development Nagoya University. Jahan. Discussion Paper № 174 .

8. Korzhenko V. V. (2016). "The phenomenon of philosophyas "Practical wisdom” of state governance”, Theory and Practice of Public Administration, vol. 2 (53), p. 1-7.

9. Geert Bouckaert, Mzia Mikeladze. (2009). The NISPAcee Journal of Public Administration and Policy, vol. I, № 2, winter 2008/2009.

10. Maslow A. H. (1943). "A theory of human motivation." Psychological Review. 50 (4), p. 370-396.

11. Lenski G. E. (1966). Power and Privilege. A Theory of Social Stratification. New York: McGrawHill.

12. Childe Gordon V. (1951). Social evolution. Publisher: Henry Schuman. Tianer Joseph, A. 2003. The nature of complex societies, Cambridge, UK: Cambridge University Press.

13. Haas Jonathon (1982). The Evolution of the Prehistoric State. Columbia University Press, New York.

14. Strange J. (2005). Center of Gravity and Critical Vulnerabilities. Quantico,
VA., USA, Marine Corps University, Defense automated printing service center [E-Reader Version]. Retrieved from: http://jfsc.ndu.edu/Portals/72/ Documents/JC2IOS/Additional_ Reading/3B_COG_and_Critical_ Vulnerabilities.pdf

15. Bielska T. V., Naplyokov $Y . \quad V$. (2017). Maximum allowable risk in decision-making process. // Public Management. № 7 (2). p. 76-88. Retrieved from http://vadnd.org.ua/ app/uploads/2017/07/Англ.pdf

16. Ashby Ross W. (1957). An Introduction to Cybernetics. Second Impression. London: Chapman \& Hall LTD.

17. Solovyov V. S. (1873-1877). Kryza zakhidnoi filosofii [The crisis of Western philosophy], $2^{\text {nd }}$ ed, Book Society Prosvita. St. Petersburg, Russian Empire.

18. Sidoruk O. (2016). Detsentralizatsiia: rezul'taty, vyklyk i perspektyvy [Decentralization: Results, Challenges and Prospects], Analytical report. Democratic Initiative Foundation named after Ilk Kucheriv. Kyiv, Ukraine.

19. Senge P. M. (2006). The Fifth Discipline: The Art \& Practice of the Learning Organization. New York, N.Y.: Doubleday.

20. Gerras Stephen J. (2008). Thinking Critically about Critical Thinking: A Fundamental Guide for Strategic Leaders, Planner's Handbook for Operational Design.

21. Kyiv International Institute of Sociology. (2016). Decentralization and local self-government reform: results of the second wave of sociological research, Analytical report. December 2016.

22. Laboratory of legitimate initiatives. (2018). Shadow Report on Reforms of state service and PA in Ukraine in 2017. U.S. Aid. Kyiv.

23. Katrenko A. V., Parsternak O. V. (2015). "Theproblem ofoptimality in the theory and practice of decision-making", 
Visnyk Natsional'noho universytetu "L’vivs'ka politekhnika”, vol. № 829, p. 359-373.

24. Naplyokov Y. V. (2018). "Changing of mental models for effective decisionmaking" // Public Management № 1 (11). p. 189-206. Retrieved from: http://vadnd.org.ua/ua/collection/

25. Naplyokov Y. V. (2014). "An Algorithm for Maintaining Dynamic Equilibrium to Achieve Strategic Goals.” Master's Thesis, U.S. Army War College, Carlisle Barracks, Pennsylvania 17013, USA.

26. Naplyokov Y. V. (2018). The archetypal foundations of value choice in the process of adaptation to the modern society // Public Management. № 4 (14). p. 171-183. Retrieved from: http://pub-management. com/index.php/about/article/ view/109/94

27. Allen C. D. (2012). "Creative Thinking for Individuals and Teams.” An essay on creative thinking for military professionals. U.S. Army War College. Retrieved from: http://www.au.af.mil/ au/awc/awcgate/army-usawc/allen creative_thkg_sr_ldrs.pdf

28. Headquarters, Department of the Army (2015), FM 6-0, Commander and Staff Organization and Operations. Washington, DC, USA, DOI: 104216001.

29. Bernhard I. (2013). E-government and E-governance - Swedish Case Studies with Focus on the Local Level. Stockholm, Sweden: KTH, Royal Institute of Technology. Available at: https://www.diva-portal.org/smash/ get/diva2:663249/FULLTEXT01.pdf

30. Heeks R. (2001). Building e-Governance for Development: A Framework for National and Donor Action. EGovernment Working Paper Series, № 12. Available at: http://unpan1. un.org/intradoc/groups/public/documents/NISPAcee/UNPAN015485.pdf. 